\title{
Stress resistance and $\mathrm{C} 1$ metabolism involved in plant colonization of a methanotroph Methylosinus sp. B4S.
}

\section{$\operatorname{AUTHOR}(\mathrm{S})$ :}

Iguchi, Hiroyuki; Sato, Izuru; Yurimoto, Hiroya;

Sakai, Yasuyoshi

\section{CITATION:}

Iguchi, Hiroyuki ...[et al]. Stress resistance and C1 metabolism involved in plant colonization of a methanotroph Methylosinus sp. B4S.. Archives of microbiology 2013, 195(10-11): 717-726

\section{ISSUE DATE:}

2013-11

URL:

http://hdl.handle.net/2433/193027

\section{RIGHT:}

The final publication is available at Springer via http://dx.doi.org/10.1007/s00203-0130922-6.; この論文は出版社版でありません。引用の際には出版社版をご確認ご利用くだ さい。; This is not the published version. Please cite only the published version. 


\title{
Stress resistance and $\mathrm{C} 1$ metabolism involved in plant colonization of a methanotroph Methylosinus sp. B4S
}

\author{
Hiroyuki Iguchi ${ }^{1,2}$, Izuru Sato ${ }^{1}$, Hiroya Yurimoto ${ }^{1}$ \\ and Yasuyoshi Sakai ${ }^{1,2, *}$
}

${ }^{1}$ Division of Applied Life Sciences, Graduate School of Agriculture, Kyoto University, Kitashirakawa-Oiwake, Sakyo-ku, Kyoto 606-8502, Japan.

${ }^{2}$ Advanced Low Carbon Technology Research and Development Program, Japan Science and Technology Agency, K's Gobancho, 7, Gobancho, Chiyoda-ku, Tokyo 102-0076, Japan.

* Corresponding author:

Yasuyoshi Sakai, Ph.D.

Professor

Division of Applied Life Sciences, Graduate School of Agriculture, Kyoto University, Kitashirakawa-Oiwake, Sakyo-ku, Kyoto 606-8502, Japan.

Phone: +8175753 6385. Fax: +81757536454.

E-mail: ysakai@kais.kyoto-u.ac.jp

Keywords: PhyR, general stress response, phyllosphere, methane monooxygenase, methanol. 


\section{ABSTRACT}

Methanotrophs are widespread and have been isolated from various environments including the phyllosphere. In this study, we characterized the plant colonization by Methylosinus sp. B4S, an $\alpha$-proteobacterial methanotroph isolated from plant leaf. The gfp-tagged Methylosinus sp. B4S cells were observed to colonize Arabidopsis leaf surfaces by forming aggregates. We cloned and sequenced the general stress response genes, phyR, nepR and ecfG, from Methylosinus sp. B4S. In vitro analysis showed that the phyR expression level was increased after heat shock challenge, and PhyR was shown to be involved in resistance to heat shock and UV light. In the phyllospheric condition, the gene expression level of phyR as well as mmoX and mxaF was found to be relatively high, compared with methane-grown liquid cultures. The phyR-deletion strain as well as the wild type strain inoculated on Arabidopsis leaves proliferated at the initial phase, and then gradually decreased during plant colonization. These results have shed light firstly on the importance of general stress resistance and C1 metabolism in methanotroph living in the phyllosphere. 


\section{INTRODUCTION}

Methanotrophs are a unique group of bacteria that utilize methane as their sole source of carbon and energy, and are important players in carbon and nitrogen cycle (Hanson \& Hanson 1996). Methane oxidation by methanotrophs also contributes to the mitigation of global warming. Methanotrophs have been found in a wide variety of environments in which methane-air interfaces develop including wetlands, peat bogs, lakes, groundwater, rice paddies, landfills, volcanoes and marine sediments (Semrau et al. 2010).

Our previous study showed that methanotrophs inhabit the phyllosphere of various plant species (Iguchi et al. 2012). Plant-associated environments are known to be important methane sources and sinks. Some plants generate methane from the methyl ester groups of pectin (Keppler et al. 2006). Wetland plants that develop aerenchyma tissue transport methane generated by methanogens from ground into the atmosphere (Aulakh et al. 2000). Plant roots supply organic compounds and oxygen, thus stimulating microbial activities including methane oxidation in the rhizosphere (Hanson \& Hanson 1996). Further, the phyllosphere is clearly distinct from soil and aqueous environments for microorganisms, in terms of nutrient availability, stress and physical structure. However, little is known about colonization of methanotroph, carbon metabolism and adaptation to stresses in the phyllosphere.

The phyllosphere is thought to be a hostile environment since the inhabitants are exposed to various stresses such as temperature change, UV radiation, desiccation, osmotic pressure, reactive oxygen species (ROS) and starvation (Lindow \& Brandl 2003; Whipps et al. 2008). It was recently reported that PhyR, which is involved in the general stress response, was necessary for plant colonization by several $\alpha$-Proteobacteria (Gourion et al. 2006; Gourion et al. 2008; Gourion et al. 2009; 
Kaczmarczyk et al. 2011). The phyR gene encodes a response regulator, and PhyR induces resistance to stresses such as heat-shock, UV radiation, desiccation and osmotic pressure (Gourion et al. 2006; Gourion et al. 2008; Gourion et al. 2009; Kaczmarczyk et al. 2011). phyR orthologues are predicted to be present in essentially all $\alpha$-Proteobacteria (Gourion et al. 2006), which are known to be the predominant population in the phyllosphere (Delmotte et al. 2009; Redford et al. 2010; Vorholt 2012). Therefore, the general stress system regulated by PhyR might be a strategy to enhance fitness in plant-associated environments. According to the proposed regulatory model, in the absence of stress, PhyR is inactivated and the ECF $\sigma$ factor EcfG is sequestered by its anti- $\sigma$ factor NepR. In response to stress, PhyR is phosphorylated by a histidine kinase PhyK and interacts with NepR, thus releasing EcfG and allowing EcfG to associate with RNA polymerase to transcribe stress genes (Francez-Charlot et al. 2009; Lourenco et al. 2011). These $p h y R, n e p R, e c f G$ and $p h y K$ genes are often clustered in the genome (Staron \& Mascher 2010).

Most of methanotrophs are obligate C1-utilizers (Semrau et al. 2011). In C1 metabolism, methane is oxidized by methane monooxygenase (MMO) to methanol, which is subsequently oxidized to formaldehyde by methanol dehydrogenase. Formaldehyde is assimilated into biomass or further oxidized to $\mathrm{CO}_{2}$, providing reducing equivalents for biosynthesis. MMO exists in two distinct forms, $\mathrm{pMMO}$ and sMMO, and methanotrophs possess both or either form of MMO (Semrau et al. 2010). pMMO and sMMO are expressed under conditions of high and low copper concentrations, respectively, and the expression is regulated at the transcriptional level (Lieberman \& Rosenzweig 2004; Nielsen et al. 1997).

We have isolated $\alpha$ - and $\gamma$-proteobacterial methanotrophs belonging to the genus Methylosinus Methylocystis and Methylmonas from plants (Iguchi et al. 2012). In 
this study, we used a methanotroph Methylosinus sp. B4S isolated from reed leaf to characterize plant colonization of methanotroph. We observed colonization of GFP-tagged Methylosinus sp. B4S on Arabidopsis leaves, and examined the involvement of PhyR and C1 metabolism in plant colonization. These results reveal life of methanotroph in the phyllosphere. 


\section{MATERIALS AND METHODS}

Bacterial strains and media. The strains and plasmids used in the present study are listed in Table 1. Methanotrophic strains were usually cultivated in nitrate mineral salt (NMS) medium (ATCC 1306 medium, plus $3 \mathrm{nM} \mathrm{CuCl}_{2}$ ) with $20 \%$ atmospheric methane at $28^{\circ} \mathrm{C}$, as described previously (Iguchi et al. 2012). When required, ampicillin $(\mathrm{Ap})$, kanamycin $(\mathrm{Km})$ or gentamycin $(\mathrm{Gm})$ were added to a final concentration of 50, 20 or $10 \mu \mathrm{g} / \mathrm{ml}$, respectively.

Utilizable carbon and nitrogen sources. The ability of strain B4S to utilize various carbon sources was tested in liquid NMS medium. Methanol, formamide and ethanol were added at $0.05 \%(\mathrm{v} / \mathrm{v})$. The following compounds were tested at a concentration of $0.1 \%(\mathrm{w} / \mathrm{v})$ : methylamine, formate, glucose, sucrose, galactose, lactose, fructose, citrate, succinate, pyruvate and acetate. Utilization of various nitrogen sources was tested in liquid NMS medium with methane, in which potassium nitrate was replaced by one of the following compounds at $0.05 \%(\mathrm{w} / \mathrm{v})$ : ammonium chloride, sodium nitrite, urea, glycine, alanine, lysine, arginine, glutamate, glutamine, aspartate, asparagine, tryptophan, methionine, threonine, cysteine or histidine.

Construction of a $\boldsymbol{g} f \boldsymbol{p}$-expressing strain. The $g f p$ gene under the control of the $m x a F$ gene promoter was introduced into the chromosome using a transposon delivery system. The primers used in this study are listed in Table S1. Here, PCR was performed using KOD FX DNA polymerase (Toyobo, Osaka, Japan), which generates the blunt-ended amplicon. At first, to obtain the mxaF promoter sequence in strain B4S, the upstream region of $m x a F$ was cloned by inverse PCR using primers mxaF1023-INV and mxaF1541-INV, and sequenced. Then, the mxaF gene promoter region (300 bp) was amplified by PCR from the genomic DNA of strain B4S with the primers PmxaF-Fw and PmxaF-Re, and cloned into the EcoRV site of pBluescript II SK+, resulting in 
pSG1201. The $g f p$ gene which was amplified by PCR from pDCG-1 with the primers gfp-Fw and gfp-Re was cloned into the EcoRV site of pSG1201, resulting in pSG1202. The correct orientation of the insert was confirmed by sequencing. The Not I fragment of pSG1202 was cloned into the NotI site of pUTmini-Tn5 Km, resulting in pSG1203.

The procedure for conjugating plasmids from $E$ coli S17-1 $\lambda$ pir into methanotrophs was based on the methods (Csaki et al. 2003). Donor cells (E. coli harboring pSG1203) and recipient cells (Methylosinus sp. B4S strains) were grown to the stationary phase in LB medium and NMS medium, respectively. The cultures were harvested by centrifugation, and mixed in a polypropylene tube. Cells were spotted on a NMS agar plate containing $0.01 \%$ Bacto tryptone, and the plate was incubated at $28^{\circ} \mathrm{C}$ under methane/air gas mixture for 1 day. Then, the cells were resuspended in NMS medium, and spread on NMS agar containing $0.01 \%$ Bacto tryptone and $\mathrm{Km}$. After the cells were grown under a methane/air gas mixture, Km-resistant and Ap-sensitive colonies were selected.

Cloning of phyR gene. The partial fragment of phyR was amplified by PCR from the genomic DNA of strain B4S with the primers phyR424-Fw and phyR668-Re, which were designed on the basis of the conserved region of phyR (Fig. S2). Sequencing was performed using a BigDye Terminator v3.1 Cycle Sequencing Kit and ABI 3130 genetic analyzer (Applied Biosystems, Foster city, CA).

Based on the partial phyR sequence obtained, the phyR locus was cloned by inverse PCR and sequenced. The genomic DNA of strain B4S was digested with EcoRI or HindIII, and the resultant fragments were self-ligated with T4 DNA ligase. One fragment, the 5'region of phyR, was amplified by PCR from the HindIII ligation product with the primers phyR-INVu2 and phyR-INVd1. Another fragment, 3' region of phyR, was amplified from the EcoRI ligation product with the primers phyR-INVu1 and 
phyR-INVd1.

Construction of a phyR-deletion mutant. The phyR-deletion mutant was generated by homologous recombination. The upstream (1210 bp) and downstream (770 bp) fragments of phyR were amplified by PCR from the genomic DNA. The PCR primers used were phyR381-Fw and phyR1590-Re for the upstream fragment, and phyR2001-Fw and phyR2770-Re for the downstream fragment. The upstream fragment was cloned into pUC19 using the BamHI and KpnI sites, and then the downstream fragment was cloned using the KpnI and EcoRI sites, resulting in pSG1101. The gentamycin resistance gene generated from $\mathrm{p} 34 \mathrm{~S}-\mathrm{Gm}$ by KpnI digestion was cloned into the KpnI site of pSG1101, resulting in pSG1102. The kanamycin $(\mathrm{Km})$ resistance gene in pK18mob was replaced by the ampicillin resistance gene which was amplified by PCR from pBR322 with the primers bla-Fw and bla-Re, using BglII and NcoI sites, resulting in pK18mob-bla. The BamHI-SphI digested fragment of pSG1102 was ligated to pK18mob-bla using the same sites, resulting in pSG1103. This construct is expected to result in a $410 \mathrm{bp}$-deletion and insertion of the $\mathrm{Gm}$ resistance gene in the phyR gene of strain B4S. pSG1102 was introduced into the methanotroph strains by conjugation, as described above. Gm-resistant and Ap-sensitive colonies (i.e., double cross-over strain) were selected. Deletion of phyR was confirmed by diagnostic PCR and Southern blotting.

Phenotypic assays. Strains B4S and B4S-phyR were grown in NMS medium with methane to exponential growth phase. The cells were harvested by centrifugation, washed with NMS medium, and adjusted $\mathrm{OD}_{600}$ to 0.5 with NMS medium. This cell suspension was used for the following assays. (i) Heat shock resistance assay. Cell suspensions $\left(100 \mu \mathrm{l}\right.$ each) were placed in $1.5 \mathrm{ml}$ tubes and incubated at $46^{\circ} \mathrm{C}$ for 5 , 10, 15, or 20 min. Triplicate samples were prepared for each incubation time. After 
incubation, the tubes were immediately cooled on ice. Untreated cell suspension served as the control. The suspensions were diluted and spread on NMS agar plates. The colonies were counted after 14 days of incubation with methane. (ii) UV resistance assay. Cell suspensions $(100 \mu \mathrm{l}$ each $)$ were placed on the lids of $1.5 \mathrm{ml}$ tubes, and exposed to $254 \mathrm{~nm}$ UV light for $3 \mathrm{~min}$. The suspensions were diluted and spread on NMS agar plates, and colonies were counted after 14 days of incubation. Triplicate samples were conducted. (iii) Disk diffusion assay. Each $1 \mathrm{ml}$ cell suspension was mixed with $50 \mathrm{ml}$ of NMS soft agar $(0.75 \%$ agar $)$, and $4 \mathrm{ml}$ portions of this mixture were poured on NMS agar ( $2 \%$ agar). A disk ( $8 \mathrm{~mm}$ diameter) was placed at the center of each plate, and aliquots $(5 \mu \mathrm{l})$ of $1 \mathrm{M} \mathrm{H}_{2} \mathrm{O}_{2}$ or $2 \%$ methylglyoxal were deposited on the filter disks. The diameter of the inhibition circle was measured after 9 days of incubation. Four replicate samples were conducted. (iv) Osmotic stress tolerance assay. Aliquots of serial dilutions of the cell suspension were spotted on NMS agar containing $0.3 \% \mathrm{NaCl}$ or $7 \%$ sucrose. Plates were incubated with methane until colonies appeared. (v) Desiccation resistance assay. Aliquots of serial dilutions of the cell suspension were spotted on mixed cellulose ester filters $(0.45 \mu \mathrm{m}$ pore size $)$. Filters were placed on NMS agar either immediately (control) or after drying under sterile airflow on a clean bench for $30 \mathrm{~min}$. Plates were incubated with methane until colonies appeared.

Plant cultivation. Arabidopsis thaliana seeds (Col.) were sown on rockwool cubes immersed in Hoagland medium prepared with tap water. The medium contained macronutrients $(\mathrm{mM}): 2.5 \mathrm{Ca}\left(\mathrm{NO}_{3}\right)_{2}, \quad 2.5 \quad \mathrm{KNO}_{3}, \quad 0.5 \quad \mathrm{KH}_{2} \mathrm{PO}_{4}, 1.0 \quad \mathrm{MgSO}_{4}$, and micronutrients $(\mu \mathrm{M}): 42 \mathrm{KCl}, 23 \mathrm{H}_{3} \mathrm{BO}_{3}, 4.6 \mathrm{MnCl}_{2}, 0.4 \mathrm{ZnSO}_{4}, 0.1 \mathrm{H}_{2} \mathrm{MoO}_{4}, 0.16$ $\mathrm{CuSO}_{4}$, and $64 \mathrm{Fe}-\mathrm{EDTA}$. The plants were grown under an open air in a plant growth chamber (Biotron: Nippon Medical \& Chemical Instruments, Osaka, Japan) at $25^{\circ} \mathrm{C}(14$ 
hr day/ 10 hr night) with $65 \%$ humidity. Plants at 3 weeks old (6-8 leaf stage) were used for experiments.

Inoculation of methanotroph on plant leaves. Methanotroph cells grown in liquid NMS medium with methane were harvested by centrifugation, washed with water, and the suspension was adjusted to an $\mathrm{OD}_{600}$ of 0.5 (for transcriptional analysis), 0.05 (for microscopic observation) or 0.01 (for growth analysis) with water. For the former two experiments, the cell suspension was sprayed on Arabidopsis plants. For growth analysis, $5 \mu$ of the cell suspension (ca. $10^{6}$ cells) was spotted on the upper side of Arabidopsis leaf.

Confocal laser scanning microscopy. Methanotroph cells were observed using a Zeiss LSM510 META laser scanning confocal microscope equipped with a Plan-FLUAR 100x, NA 1.45 oil objective on an inverted microscope Axiovert 200M (Carl Zeiss, Oberkochen, Germany). GFP was excited with a $488 \mathrm{~nm}$ argon laser with a 505-550 nm filter for emission.

Reverse transcription-quantitative PCR (RT-qPCR) analysis. Total RNA was extracted and purified using a TRIzol reagent (Invitrogen, Carlsbad, CA). Methanotroph cells or ca. 20 leaves (from 4-5 individual plants) were frozen in liquid nitrogen, and then were disrupted with zirconia beads in TRIzol reagent. After purification according to the manufacturer's instructions, contaminating DNA was removed by DNase I treatment. The RNA was purified with acidic phenol, precipitated with ethanol, and dissolved in water.

RT reactions were done using $1 \mu \mathrm{g}$ of total RNA, SuperScript III Reverse Transcriptase (Invitrogen) and random primers (Promega, Madison, CA). qPCR analysis was carried out using a LightCycler system (Roche Diagnostics, Tokyo, Japan), SYBR Premix ExTaq (Takara Bio, Shiga, Japan) and $1 \mu$ of cDNA according to the 
manufacturer's instructions. PCR primers were designed for 16S rRNA, pmoA, mmoX, $m x a F$ and phyR of strain B4S (Table S1). Specificity of these primers was confirmed by lack of amplification from cDNA of untreated leaves. The copy number of each gene was calculated with a standard curve that was created with plasmid DNA harboring each gene. Because RNA extracted from leaves is contaminated RNA from naturally occurring bacteria and Arabidopsis, transcriptional levels between samples were normalized using the $16 \mathrm{~S}$ rRNA gene transcript as the endogenous control.

Growth measurement by qPCR. Four leaves were harvested and frozen at $-80^{\circ} \mathrm{C}$. Genomic DNA was quantitatively extracted from leaves by incubating at $65^{\circ} \mathrm{C}$ in TEN buffer (50 mM Tris-HCl, $10 \mathrm{mM}$ EDTA, $150 \mathrm{mM} \mathrm{NaCl}$, pH8) containing 1\% SDS and $200 \mu \mathrm{g} / \mathrm{ml}$ proteinase $\mathrm{K}$, followed by purification with phenol-chloroform. qPCR was carried out using a LightCycler system, SYBR Premix ExTaq and the genomic DNA as template. PCR primers targeting for $g f p$ was used (Table S1).

Nucleotide sequence accession numbers. The sequences obtained in this study have been submitted to GenBank and assigned the following accession numbers: mmoX gene, AB683148; phyR gene locus, AB741957; mxaF gene locus, AB741958. 


\section{RESULTS}

\section{Characterization and plant colonization of Methylosinus sp. B4S.}

We isolated a methanotrophic bacterium, Methylosinus sp. B4S, from reed leaf in the previous study (Iguchi et al. 2012). Strain B4S possesses the pmoA and mmoX genes, which encode particulate methane monooxygenase (pMMO) and soluble methane monooxygenase (sMMO), respectively. Strain B4S grew only on C1-compounds, i.e., methane, methanol and formate, among the tested carbon sources including organic acids and sugars, and thus is an obligate methanotroph. Utilizable nitrogen sources were nitrate, ammonium, urea, alanine, glutamine, aspartate, asparagine and cysteine. At least, methanol as a carbon source, and nitrate and ammonium as a nitrogen source, were reported to be present on plant leaves (Nemecekmarshall et al. 1995; Parangan-Smith \& Lindow 2013).

We investigated the colonization of Methylosinus sp. B4S on Arabidopsis leaves using green fluorescent protein (GFP)-tagged strains. A construct carrying the $g f p$ gene fused to the mxaF gene promoter was introduced into the chromosome by mini-Tn5 transposon system. The generated GFP strain showed the similar growth rate as the wild type strain under standard culture conditions (Fig. S1).

Strain B4S-gfp cells that were inoculated by spraying onto Arabidopsis plants were monitored with a confocal laser scanning microscopy. Figure 1a shows the leaf image of two vertical sections at 1 day post inoculation (dpi). We detected methanotroph cells exhibiting GFP fluorescence on Arabidopsis leaves. The inoculated cells were located on the surface of leaf epidermal cells, and often were aggregated in the grooves between the leaf epidermal cells (Fig. 1a right panel), which was similar to the localization pattern of Methylobacterium cells sprayed on leaves of clover or strawberry (Omer et al. 2004; Verginer et al. 2010). Since a part of strain B4S cells 
showed motility in liquid culture, this localization may be due to water drift on leaves. GFP fluorescence of the methanotroph was still observed at 7 dpi, although their fluorescence intensity declined during plant habitation (Fig. 1b).

\section{Cloning of phyR gene locus.}

Next, we cloned and analyzed phyR to characterize general stress resistance in Methylosinus sp. B4S. A partial fragment of phyR was obtained from Methylosinus sp. B4S by PCR with primers designed within the conserved sequence regions of phyR (Fig. S2 and Table S1). Then, the surrounding region was cloned by inverse PCR, as described in Materials and Methods. PhyR of Methylosinus sp. B4S shared 54\% amino acid identity with PhyR of Methylobacterium extorquens AM1 (Gourion et al. 2006). Figure 2 shows the organization of the phyR gene locus of Methylosinus sp. B4S. The phy $R$, nepR and $\operatorname{sig} T$ genes were found in an organization typical of $\alpha$-Proteobacteria where $p h y R$ is adjacent to and divergently oriented from nepR-sigT (Staron \& Mascher 2010). A gene encoding putative histidine kinase was not present in the sequenced region. orfl encodes a hypothetical protein containing the stress-induced bacterial acidophilic repeat motif, and has not been assigned to the PhyR regulatory system. This motif is characterized as the amino acid sequence KGG and is found in proteins which are expressed under stress conditions. Gene organization of the locus from ecfG to orfl was conserved among the sequenced $\alpha$-proteobacterial methanotrophs except Methylocella lacking orf1 (Chen et al. 2010; Dam et al. 2012; del Cerro et al. 2012; Stein et al. 2010; Stein et al. 2011).

The ECF $\sigma$ factor EcfG recognizes an ECF-type promoter sequence (consensus GGAAC-N ${ }_{16,17-C G T T)}$ to activate the transcription of genes (Alvarez-Martinez et al. 2007; Gourion et al. 2009). In Methylosinus sp. B4S, an ECF-type promoter sequence was found for nepR (GGAAC-N ${ }_{16}-$ CGTT-N $\left._{148}-\mathrm{ATG}\right)$ and orfl 
(GGAAC-N ${ }_{14}$-CCTT-N 48 -ATG), but not for phyR. Other methanotroph strains in the genus Methylosinus and Methylocystis also do not have an ECF-type promoter sequence upstream of phyR; however Methylocella has the sequence (Chen et al. 2010; Dam et al. 2012; del Cerro et al. 2012; Stein et al. 2010; Stein et al. 2011). This trait of methanotrophs, the absence of an ECF-type promoter sequence for $p h y R$, is unlike those of previously studied bacteria (Bastiat et al. 2010; Gourion et al. 2008; Gourion et al. 2009; Kaczmarczyk et al. 2011; Lourenco et al. 2011). These observations stimulated an interest in the expression manner of phyR in Methylosinus sp. B4S.

\section{Phy $R$ is involved in resistance to heat shock and UV radiation.}

To examine the stress resistance regulated by PhyR in Methylosinus sp. B4S, we constructed a phyR deletion mutant via homologous recombination. The mutant strain B4S-phyR ( $\triangle p h y R$ ) showed the almost same growth rate as strain B4S (wild type) in methane-grown cultures (Fig. S1), indicating that PhyR is not required for methanotrophic metabolism under standard culture conditions.

Resistance to heat shock, UV radiation, oxidative stress $\left(\mathrm{H}_{2} \mathrm{O}_{2}\right.$ and methylglyoxal), osmotic stress ( $\mathrm{NaCl}$ and sucrose), and desiccation was evaluated for wild type and $\Delta p h y R$ strains. The $\Delta p h y R$ strain was more sensitive to heat shock and UV radiation than wild type (Fig. $3 \mathrm{a}$ and $\mathrm{b}$ ). The survival rate after a challenge at $46^{\circ} \mathrm{C}$ for 20 min was 20 -fold lower for the $\Delta p h y R$ strain than the wild type strain. UV radiation for 3 min reduced the viability of the $\Delta p h y R$ strain but not that of the wild type strain. In contrast, no differences were detected in the sensitivity to $\mathrm{H}_{2} \mathrm{O}_{2}$, methylglyoxal, $\mathrm{NaCl}$, sucrose or desiccation between the wild type and $\Delta p h y R$ strains (Fig. 3c-f).

We then analyzed the expression of phyR in response to stress in flask cultures by RT-qPCR. When the Methylosinus sp. B4S culture was shifted from $28^{\circ} \mathrm{C}$ to $40^{\circ} \mathrm{C}$, transcription of phyR was elevated by 1.5 -fold (Fig. 3g). Although the induction was 
small, it was reproducible at $40^{\circ} \mathrm{C}$, and was also observed in response to heat shock at $37^{\circ} \mathrm{C}$ (1.7-fold induction, Fig. 3g). These results, together with mutant analysis, indicate that in Methylosinus sp. B4S, PhyR contributes to resistance to heat shock and UV stress, and responds to stress at the transcriptional level.

Gene expression of phyR and C1 metabolism genes in the phyllosphere.

Expression of methane monooxygenase ( $p m o A$ and mmoX) and methanol dehydrogenase genes $(m x a F)$ as well as phyR on Arabidopsis leaves was examined. Inoculation was done by spraying the cell suspension on growing Arabidopsis plants, and the plants were cultivated under a $14 \mathrm{hr}$-day/ $10 \mathrm{hr}$-night cycle. RNA was extracted in the day time from leaves, and gene expression was analyzed by RT-qPCR. To set the culture condition, growing agar and liquid cultures were experienced 1 day cultivation in the plant growth chamber before RNA extraction. Transcriptions were calculated as copy number with standard samples, and the transcriptional level of pmoA, mmoX, $m x a F$ and phyR was normalized with $16 \mathrm{~S}$ rRNA transcript in each sample. In general the $16 \mathrm{~S}$ rRNA transcriptional level changes depending on the growth phase and culture condition, and was 10-fold higher in liquid culture than on agar plates in this study. On the other hand, copper concentration in the media did not affect the 16S rRNA transcriptional level. Hence, we evaluated the transcriptional levels of phyR and $\mathrm{C} 1$ metabolism genes relative to the $16 \mathrm{~S}$ rRNA transcript within each culture (leaf, agar and liquid culture).

It was found that mmoX was more highly expressed than pmoA on Arabidopsis leaves (Fig. 4). Expression of $p m o A$ and $m m o X$ was reported to be regulated by copper ion in some methanotrophs (Semrau et al. 2010), and such copper-dependent regulation was confirmed in vitro in Methylosinus sp. B4S. As shown in Figure 4, both on agar plates and in liquid culture, $\operatorname{mmoX}$ (sMMO-encoding gene) was strongly repressed in 
the presence of copper compared to in the absence of copper addition while the repression level of pmoA (pMMO-encoding gene) was low without copper addition. Based on these expression profiles, Arabidopsis leaf surfaces were suggested to represent low copper conditions. In this study, Arabidopsis plants were cultivated in Hoagland medium $\left(\mathrm{Cu}^{2+}, 0.16 \mu \mathrm{M}\right)$ and tap water with daily replenishment; thus sufficient copper for plant growth was available. Furthermore, relatively high expression of mxaF was found on leaves (Fig. 4), suggesting that the methanotrophic cells may respond to methanol present on leaf surfaces (Hanson \& Hanson 1996).

High expression level of phyR, relative to other three $\mathrm{C} 1$ metabolism genes, was found on leaves and agar plates than in liquid culture (Fig. 4). We suspect that solid culture (i.e., leaf and agar plate) elevated phyR gene expression. During plant habitation, the transcriptional level of phyR was decreased similarly to $\mathrm{C} 1$ metabolism genes (Fig. 4), which may represent the decline in whole cellular activity, as observed with the GFP fluorescence (Fig. 1).

\section{Growth of methanotroph in the phyllosphere.}

Growth on leaves between phyR-intact and deletion strains was compared by qPCR. Inoculation with cells on Arabidopsis leaves, DNA extraction and calculation were subjected to the quantitative methods. The inoculated cells of strain B4S-gfp divided once until 3 dpi (Fig. 5). After that, the cells gradually decreased but survived for at least 9 days, which supports the results of gene expression and GFP fluorescence on Arabidopsis leaves (Fig. 1 and 4). The phyR-deletion strain (B4S-gfp-phyR) also showed similar pattern of growth (Fig. 5) and GFP fluorescence profile (data not shown). These results indicated that phyR-regulated stress resistance is not necessary for plant colonization under the growth chamber condition where methanotrophs were not exposed to heat and UV stresses. 


\section{DISCUSSION}

The phyllosphere is a distinct environment from soils and aqueous environments which have been the major targets of studies of methanotrophs, thus the life of methanotrophs in the phyllosphere would be of interest. In this study, we examined the expression of phyR and $\mathrm{C} 1$ metabolism genes on plant leaves, firstly with a methanotroph Methylosinus sp. B4S. We also assessed the ability of methanotrophs to adapt to rapid environmental changes and stresses occurring in the phyllosphere by functional analysis of PhyR.

Methylosinus sp. B4S was demonstrated to colonize Arabidopsis leaves (Fig. 1 and 5), although Arabidopsis plants were reported not to produce methane (Nisbet et al. 2009). The cell proliferation occurred in the initial 3 days after inoculation, presumably by utilizing methanol emitted from leaves and/or nutrients accumulated during pre-culture (Fig. 5). Moreover, though the cell proliferation did not continue, methanotroph was able to survive on leaves (Fig. 1 and 5). The phyR deletion strain colonized and survived on Arabidopsis leaves similarly to the wild type strain (Fig. 5). We think that cultivation of Arabidopsis plants in the growth chamber did not afford the phyR-regulated stresses, heat shock and UV radiation, to Methylosinus sp. B4S. These stresses are serious for phyllospheric microorganisms in natural environments where plant surfaces are directly irradiated by sunlight and the surface temperature is rapidly affected by the day/night cycle.

In our previous study, a microbial sensor determined the methanol concentration present on Arabidopsis leaf surfaces to be between 4-64 mM (Kawaguchi et al. 2011). Methylosinus sp. B4S cannot grow with methanol concentrations above 25 $\mathrm{mM}$ (Iguchi et al. 2012), and hence cells may suffer and accumulate a damage derived from methanol and its metabolite formaldehyde during plant habitation. Nevertheless, 
this methanotroph seems to be able to survive and colonize on plant leaves in nature. This might be explained by the fact that methanotrophs often cohabitate on plant leaves with other methanol-utilizers (Iguchi et al. 2012), which can reduce the local methanol concentration in the phyllosphere.

Methane and methanol are the main carbon sources for methanotrophs in natural environments, and are assumed to be available in the phyllosphere. To characterize the $\mathrm{C} 1$ metabolism of methanotrophs in the phyllosphere, gene expression was examined on Arabidopsis plants. Methanotrophs oxidize methane with pMMO and sMMO, depending on copper availability in the environment. Some studies of in situ methanotroph activity indicated that pMMO was largely responsible for methane oxidation in soils, since the transcript of pmoA but not $m m o X$ was detected (Chen et al. 2007; Han \& Semrau 2004). These results also suggested that soil contained sufficient amount of copper to induce $p m o A$ gene expression. Our present results indicated that both $p m o A$ and $m m o X$ were expressed in the phyllosphere (Fig. 4).

We confirmed that the copper-dependent regulation of MMO genes occurs in Methylosinus sp. B4S on agar and in liquid cultures (Fig. 4) although the repression level of pmoA transcript was very small, probably due to an influence of trace amount of copper ion contaminated in the medium. When inoculated on Arabidopsis leaves, Methylosinus sp. B4S exhibited a higher level of mmoX transcription than that of pmoA (Fig. 4), which represents the expression profile in copper-limited conditions. These results suggest that copper availability for methanotrophs is low on leaf surfaces, and hence sMMO can respond to methane oxidation in the phyllosphere. Plants regulate copper uptake using a copper transporter and employ copper chaperones to avoid the toxic effects of copper (Klaumann et al. 2011). The copper concentration is estimated to be 2-50 $\mu \mathrm{g} / \mathrm{g}$-dry weight of plant material and $4 \mu \mathrm{g} / \mathrm{g}$-dry weight of Arabidopsis leaves 
(Burkhead et al. 2009; Klaumann et al. 2011). However, these data cannot fully explain the amount of copper that microorganisms sense and utilize. To this end, the quantitative technique of in situ gene expression of microorganisms is practical. Quantitative RT-PCR analysis was used in this study to define this physiological aspect of methanotrophs on leaf surfaces.

The present study characterized the in situ activity of methanotroph in the phyllosphere. It was found that PhyR of the methanotroph Methylosinus sp. B4S regulates resistance to heat and UV stress, and C1 metabolism genes were expressed and regulated in the phyllosphere. These cellular functions are expected to play an important role in habitation of methanotrophs in natural environment. 


\section{ACKNOWLEDGMENTS}

This study was supported in part by a Grant-in-Aid for Scientific Research (B) (22380052, to Y.S.) and a Grant-in-Aid for Scientific Research (B) (22310046, to H.Y.) from the Japan Society for the Promotion of Science, and Advanced Low Carbon Technology Research and Development Program (ALCA) from Japan Science and Technology Agency. 


\section{REFERENCES}

Alvarez-Martinez CE, Lourenco RF, Baldini RL, Laub MT \& Gomes SL (2007) The ECF sigma factor $\sigma^{\mathrm{T}}$ is involved in osmotic and oxidative stress responses in Caulobacter crescentus. Mol Microbiol 66:1240-1255

Aulakh MS, Wassmann R, Rennenberg H \& Fink S (2000) Pattern and amount of aerenchyma relate to variable methane transport capacity of different rice cultivars. Plant Biology 2:182-194

Bastiat B, Sauviac L \& Bruand C (2010) Dual control of Sinorhizobium meliloti RpoE2 sigma factor activity by two PhyR-type two-component response regulators. J Bacteriol 192:2255-2265

Burkhead JL, Reynolds KAG, Abdel-Ghany SE, Cohu CM \& Pilon M (2009) Copper homeostasis. New Phytol 182:799-816

Chen Y, Dumont MG, Cebron A \& Murrell JC (2007) Identification of active methanotrophs in a landfill cover soil through detection of expression of $16 \mathrm{~S}$ rRNA and functional genes. Environ Microbiol 9:2855-2869

Chen Y, Crombie A, Rahman MT et al. (2010) Complete genome sequence of the aerobic facultative methanotroph Methylocella silvestris BL2. J Bacteriol $192: 3840-3841$

Csaki R, Bodrossy L, Klem J, Murrell JC \& Kovacs KL (2003) Genes involved in the copper-dependent regulation of soluble methane monooxygenase of Methylococcus capsulatus (Bath): cloning, sequencing and mutational analysis. Microbiology 149:1785-1795

Dam B, Dam S, Kube M, Reinhardt R \& Liesack W (2012) Complete genome sequence of Methylocystis sp. strain SC2, an aerobic methanotroph with high-affinity methane oxidation potential. J Bacteriol 194:6008-6009 
del Cerro C, Garcia JM, Rojas A, Tortajada M, Ramon D, Galan B, Prieto MA \& Garcia JL (2012) Genome sequence of the methanotrophic poly- $\beta$-hydroxybutyrate producer Methylocystis parvus OBBP. J Bacteriol 194:5709-5710

Delmotte N, Knief C, Chaffron S, Innerebner G, Roschitzki B, Schlapbach R, von Mering C \& Vorholt JA (2009) Community proteogenomics reveals insights into the physiology of phyllosphere bacteria. Proc Natl Acad Sci U S A $106: 16428-16433$

Dennis JJ \& Zylstra GJ (1998) Plasposons: modular self-cloning minitransposon derivatives for rapid genetic analysis of gram-negative bacterial genomes. Appl Environ Microbiol 64:2710-2715

Francez-Charlot A, Frunzke J, Reichen C, Ebneter JZ, Gourion B \& Vorholt JA (2009) Sigma factor mimicry involved in regulation of general stress response. Proc Natl Acad Sci U S A 106:3467-3472

Gourion B, Rossignol M \& Vorholt JA (2006) A proteomic study of Methylobacterium extorquens reveals a response regulator essential for epiphytic growth. Proc Natl Acad Sci U S A 103:13186-13191

Gourion B, Francez-Charlot A \& Vorholt JA (2008) PhyR is involved in the general stress response of Methylobacterium extorquens AM1. J Bacteriol 190:1027-1035

Gourion B, Sulser S, Frunzke J, Francez-Charlot A, Stiefel P, Pessi G, Vorholt JA \& Fischer HM (2009) The PhyR- $\sigma^{\text {EcfG }}$ signalling cascade is involved in stress response and symbiotic efficiency in Bradyrhizobium japonicum. Mol Microbiol 73:291-305

Han JI \& Semrau JD (2004) Quantification of gene expression in methanotrophs by competitive reverse transcription-polymerase chain reaction. Environ Microbiol 
6:388-399

Hanson RS \& Hanson TE (1996) Methanotrophic bacteria. Microbiol Rev 60:439-471

Iguchi H, Sato I, Sakakibara M, Yurimoto H \& Sakai Y (2012) Distribution of methanotrophs in the phyllosphere. Biosci Biotechnol Biochem 76:1580-1583

Kaczmarczyk A, Campagne S, Danza F, Metzger LC, Vorholt JA \& Francez-Charlot A (2011) Role of Sphingomonas sp. strain Fr1 PhyR-NepR- $\sigma^{\text {EcfG }}$ cascade in general stress response and identification of a negative regulator of PhyR. J Bacteriol 193:6629-6638

Kawaguchi K, Yurimoto H, Oku M \& Sakai Y (2011) Yeast methylotrophy and autophagy in a methanol-oscillating environment on growing Arabidopsis thaliana leaves. PLoS ONE 6:e25257

Keppler F, Hamilton JTG, Brass M \& Rockmann T (2006) Methane emissions from terrestrial plants under aerobic conditions. Nature 439:187-191

Klaumann S, Nickolaus SD, Furst SH, Starck S, Schneider S, Neuhaus HE \& Trentmann O (2011) The tonoplast copper transporter COPT5 acts as an exporter and is required for interorgan allocation of copper in Arabidopsis thaliana. New Phytol 192:393-404

Kobayashi K (2007) Bacillus subtilis pellicle formation proceeds through genetically defined morphological changes. J Bacteriol 189:4920-4931

Lieberman RL \& Rosenzweig AC (2004) Biological methane oxidation: regulation, biochemistry, and active site structure of particulate methane monooxygenase. Crit Rev Biochem Mol Biol 39:147-164

Lindow SE \& Brandl MT (2003) Microbiology of the phyllosphere. Appl Environ Microbiol 69:1875-1883

Lourenco RF, Kohler C \& Gomes SL (2011) A two-component system, an anti-sigma 
factor and two paralogous ECF sigma factors are involved in the control of general stress response in Caulobacter crescentus. Mol Microbiol 80:1598-1612 Nemecekmarshall M, Macdonald RC, Franzen FJ, Wojciechowski CL \& Fall R (1995) Methanol emission from leaves: enzymatic detection of gas-phase methanol and relation of methanol fluxes to stomatal conductance and leaf development. Plant Physiol 108:1359-1368

Nielsen AK, Gerdes K \& Murrell JC (1997) Copper-dependent reciprocal transcriptional regulation of methane monooxygenase genes in Methylococcus capsulatus and Methylosinus trichosporium. Mol Microbiol 25:399-409

Nisbet RE, Fisher R, Nimmo RH et al. (2009) Emission of methane from plants. Proc R Soc B 276:1347-1354

Omer ZS, Tombolini R \& Gerhardson B (2004) Plant colonization by pink-pigmented facultative methylotrophic bacteria (PPFMs). FEMS Microbiol Ecol 47:319-326

Parangan-Smith A \& Lindow S (2013) Contribution of nitrate assimilation to the fitness of Pseudomonas syringae pv. syringae B728a on plants. Appl Environ Microbiol 79:678-687

Redford AJ, Bowers RM, Knight R, Linhart Y \& Fierer N (2010) The ecology of the phyllosphere: geographic and phylogenetic variability in the distribution of bacteria on tree leaves. Environ Microbiol 12:2885-2893

Schafer A, Tauch A, Jager W, Kalinowski J, Thierbach G \& Puhler A (1994) Small mobilizable multi-purpose cloning vectors derived from the Escherichia coli plasmids pK18 and pK19: selection of defined deletions in the chromosome of Corynebacterium glutamicum. Gene 145:69-73

Semrau JD, DiSpirito AA \& Yoon S (2010) Methanotrophs and copper. FEMS Microbiol Rev 34:496-531 
Semrau JD, DiSpirito AA \& Vuilleumier S (2011) Facultative methanotrophy: false leads, true results, and suggestions for future research. FEMS Microbiol Lett 323:1-12

Staron A \& Mascher T (2010) General stress response in $\alpha$-proteobacteria: PhyR and beyond. Mol Microbiol 78:271-277

Stein LY, Yoon S, Semrau JD et al. (2010) Genome sequence of the obligate methanotroph Methylosinus trichosporium strain OB3b. J Bacteriol $192: 6497-6498$

Stein LY, Bringel F, DiSpirito AA et al. (2011) Genome sequence of the methanotrophic alphaproteobacterium Methylocystis sp. strain Rockwell (ATCC 49242). J Bacteriol 193:2668-2669

Verginer M, Siegmund B, Cardinale M, Muller H, Choi Y, Miguez CB, Leitner E \& Berg G (2010) Monitoring the plant epiphyte Methylobacterium extorquens DSM 21961 by real-time PCR and its influence on the strawberry flavor. FEMS Microbiol Ecol 74:136-145

Vorholt JA (2012) Microbial life in the phyllosphere. Nat Rev Microbiol 10:828-840

Whipps JM, Hand P, Pink D \& Bending GD (2008) Phyllosphere microbiology with special reference to diversity and plant genotype. J Appl Microbiol $105: 1744-1755$ 


\section{Figure legends}

Fig. 1. Colonization of Methylosinus sp. B4S-gfp on Arabidopsis leaves. Confocal laser scanning microscope images of Arabidopsis leaves at 1 day (a) and 7 days (b) post inoculation with Methylosinus sp. B4S-gfp. Pictures include orthogonal sections of a stack image. Panel b represents two vertical sections in one viewpoint, showing colonization on the leaf surfaces (left) and in the leaf grooves (right). Scale bar: $10 \mu \mathrm{m}$.

Fig. 2. Organization of the phyR gene locus in Methylosinus sp. B4S. Truncated genes found in the sequenced border region are shown with dotted lines.

Fig. 3. Stress resistance and response in Methylosinus sp. B4S (WT) and B4S-phyR $(\Delta p h y R)$ strains. (a, b) Thermal (a) and UV light (b) resistance assessed by viability after cells were incubated at $46^{\circ} \mathrm{C}$ for indicated time or exposure to UV light ( $\left.254 \mathrm{~nm}\right)$ for $3 \mathrm{~min}$. The percentage of viability corresponds to the CFU ratio of treated to untreated cells. (c, d) Resistance to $\mathrm{H}_{2} \mathrm{O}_{2}$ (c) and methylglyoxal (d) determined by disk diffusion assays. Data represent the diameter of the inhibition halo created on agar plates. (e) Ability to grow in media containing $0.3 \% \mathrm{NaCl}$ or $7 \%$ sucrose. A dilution series of cells was spotted on NMS agar. Shown is the plate after cultivation for 7 days (control), 9 days ( $\mathrm{NaCl}$ plate), and 11 days (sucrose plate). (f) Cell viability after desiccation challenge. A dilution series of cells was spotted on filter paper, and the filters were laid on NMS agar plates immediately or after 30 min-drying under sterile air flow. Shown is the filter after cultivation for 10 days (control) and 14 days (30 min dry). (g) Transcriptional level of phyR in the absence $\left(28^{\circ} \mathrm{C}\right)$ and presence $\left(40\right.$ or $\left.37^{\circ} \mathrm{C}, 1 \mathrm{hr}\right)$ of heat stress was analyzed by RT-qPCR for liquid cultures of strain B4S. (a to g) Data are the means of three replicates $(\mathrm{a}, \mathrm{b})$ or four replicates $(\mathrm{c}, \mathrm{d}, \mathrm{g})$, and one representative 
from three replicates $(\mathrm{e}, \mathrm{f})$. Error bars represent standard deviations. Asterisks indicate significant increases between two samples $(t$ test; *, $\mathrm{P}<0.05$; **, $\mathrm{P}<0.1)$.

Fig. 4. Gene expression on Arabidopsis leaves. Gene expression of Methylosinus sp. B4S was analyzed by RT-qPCR on Arabidopsis leaves, NMS agar plates and NMS liquid cultures. Before RNA extraction, the agar and liquid cultures were incubated for 1 day in the plant growth chamber. Shown are the relative transcriptional levels in which the copy numbers of each gene calculated with standard samples were normalized with 16S rRNA transcript. Data are the means of three replicate samples. Error bars represent standard deviations.

Fig. 5. Growth profile on Arabidopsis leaves. The number of plant colonized cells of Methylosinus sp. B4S strains was determined by qPCR. Data are the means of four replicates. Error bars represent standard deviations. 
Fig. S1. Growth and methane consumption of Methylosinus sp. B4S in liquid culture. Methanotrophs were cultured in NMS medium with methane. Antibiotics were excluded from the media. Data are the means of triplicate samples. Error bars represent standard deviations.

Fig. S2. Nucleotide sequence alignment of the phyR genes from four bacterial strains. Shading indicates the conserved bases in three out of four strains. Arrows indicate the regions used to design universal PCR primers for the phyR gene. Primer sequences are shown in Table S1. Full names of bacteria and gene loci: Methylobacterium extorquens AM1 (MexAM1_META1p3110); Bradyrhizobium japonicum USDA 110 (bll7795); Methylocella silvestris BL2 (Msi10286); Sinorhizobium meliloti 1021 (Smc01504). 
Table 1 Bacterial strains and plasmids used in this study

\begin{tabular}{|c|c|c|}
\hline Strain or plasmid & Characteristics & Reference or source \\
\hline \multicolumn{3}{|l|}{ Strains } \\
\hline \multicolumn{3}{|l|}{ Methylosinus sp. } \\
\hline $\mathrm{B} 4 \mathrm{~S}$ & Wild type & Iguchi et al. (2012) \\
\hline B4S-gfp & B4S $\mathrm{P}_{m x a F}-g f p \mathrm{Km}^{\mathrm{R}}$ & This study \\
\hline B4S-phyR & $\mathrm{B} 4 \mathrm{~S} \triangle p h y R:: \mathrm{Gm}^{\mathrm{R}}$ & This study \\
\hline B4S-gfp-phyR & B4S-gfp $\Delta p h y R:: \mathrm{Gm}^{\mathrm{R}}$ & This study \\
\hline E.coli S17-1 $\lambda$ pir & recA thi pro hsdRM ${ }^{+} \mathrm{RP} 4-2-\mathrm{Tc}:: \mathrm{Mu}-\mathrm{Km}:: \mathrm{Tn} 7$ ppir & Biomedal Inc. \\
\hline \multicolumn{3}{|l|}{ Plasmids } \\
\hline pUC19 & Cloning vector, $\mathrm{Ap}^{\mathrm{R}}$ & Takara Bio Inc. \\
\hline pBluescript II SK+ & Cloning vector, $\mathrm{Ap}^{\mathrm{R}}$ & Stratagene Inc. \\
\hline pBR322 & Source of $A p^{R}$ cassette, $A p^{R}$ & Takara Bio Inc. \\
\hline p34S-Gm & Source of $\mathrm{Gm}^{\mathrm{R}}$ cassette, $A p^{\mathrm{R}} \mathrm{Gm}^{\mathrm{R}}$ & Dennis \& Zylstra (1998) \\
\hline pDCG-1 & Source of $g f p, \mathrm{Ap}^{\mathrm{R}} \mathrm{Cm}^{\mathrm{R}}$ & Kobayashi (2007) \\
\hline pUTmini-Tn5 Km & Transposon vector, $\mathrm{Ap}^{\mathrm{R}} \mathrm{Km}^{\mathrm{R}}$ mini-Tn5 RP4-mob & Biomedal Inc. \\
\hline pK18mob & Mobilizable cloning vector, $\mathrm{Km}^{\mathrm{R}} \mathrm{RP} 4-m o b$ & Schafer et al. (1994) \\
\hline pK18mob-bla & pK18mob carrying $A p^{R}$ replacing $\mathrm{Km}^{\mathrm{R}}, \mathrm{Ap}^{\mathrm{R}}$ & This study \\
\hline pSG1101 & pUC19 carrying upstream and downstream of $p h y R, \mathrm{Ap}^{\mathrm{R}}$ & This study \\
\hline pSG1102 & pSG1101 carrying $\Delta p h y R:: \mathrm{Gm}^{\mathrm{R}}, \mathrm{Ap}^{\mathrm{R}} \mathrm{Gm}^{\mathrm{R}}$ & This study \\
\hline pSG1103 & pK18mob-bla carrying $\Delta p h y R:: \mathrm{Gm}^{\mathrm{R}}, \mathrm{Ap}^{\mathrm{R}} \mathrm{Gm}^{\mathrm{R}}$ & This study \\
\hline pSG1201 & pBluescript II SK+ carrying the $m x a F$ promoter, $\mathrm{Ap}^{\mathrm{R}}$ & This study \\
\hline pSG1202 & pSG1201 carrying the $m x a F$ promoter fused with $g f p, \mathrm{Ap}^{\mathrm{R}}$ & This study \\
\hline pSG1203 & $\begin{array}{l}\text { pUTmini-Tn5 Km carrying the } m x a F \text { promoter fused with } \\
g f p, \mathrm{Ap}^{\mathrm{R}} \mathrm{Km}^{\mathrm{R}}\end{array}$ & This study \\
\hline
\end{tabular}


(a)

(b)
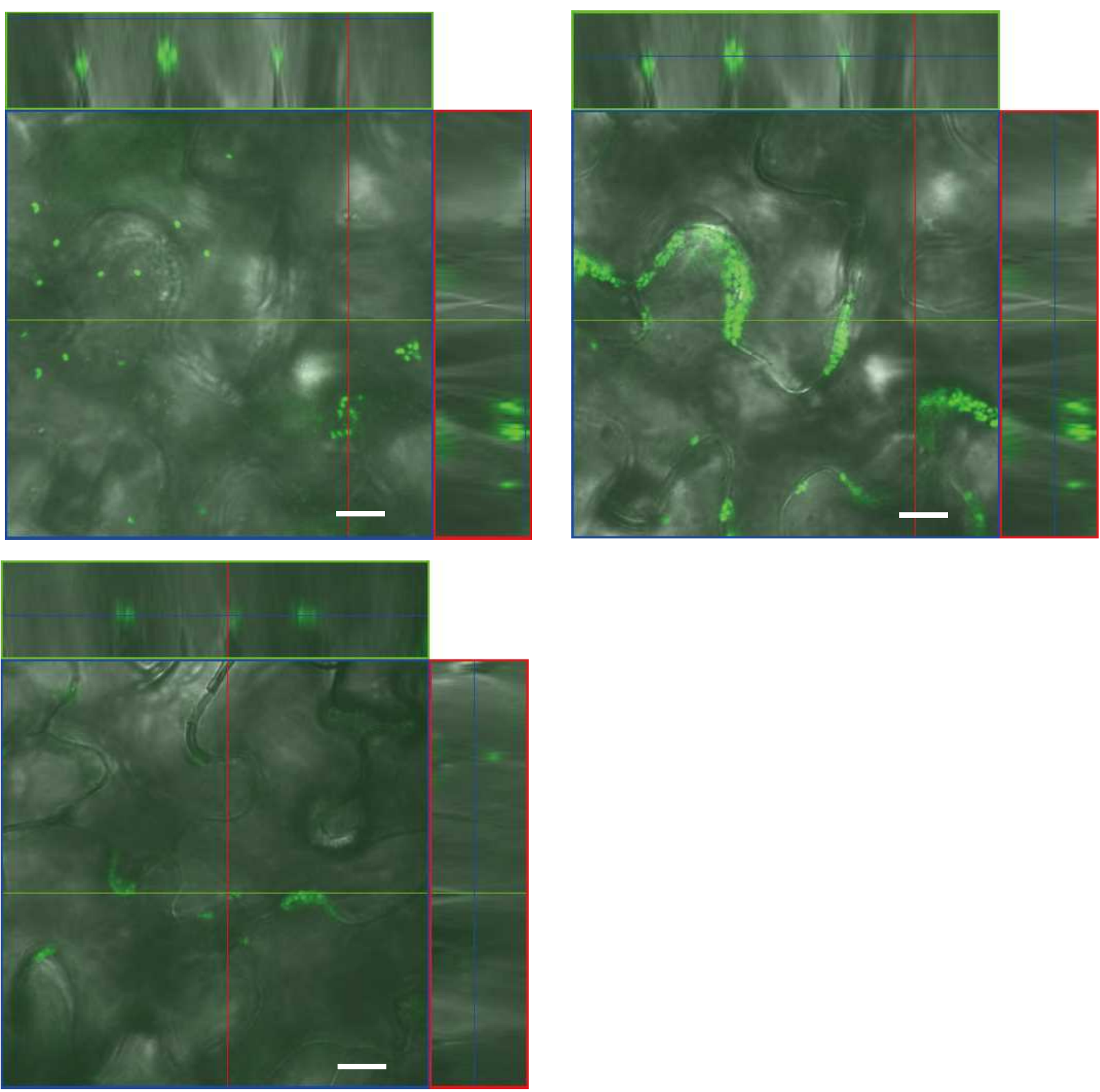

Figure 1 


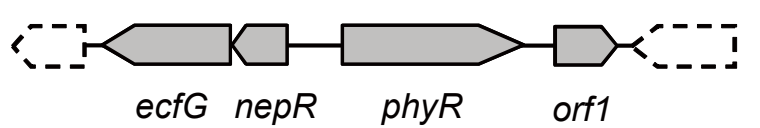

$500 \mathrm{bp}$

Figure 2 


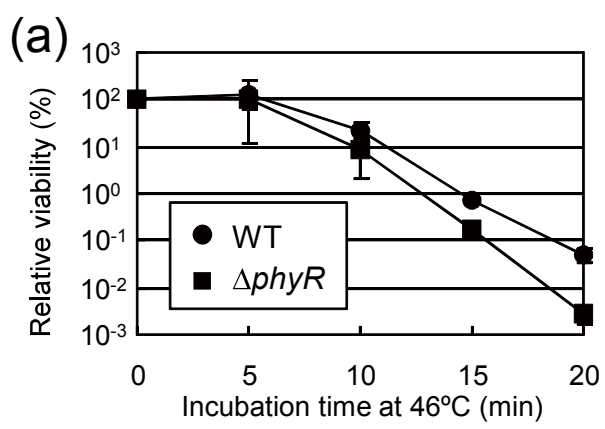

(e)
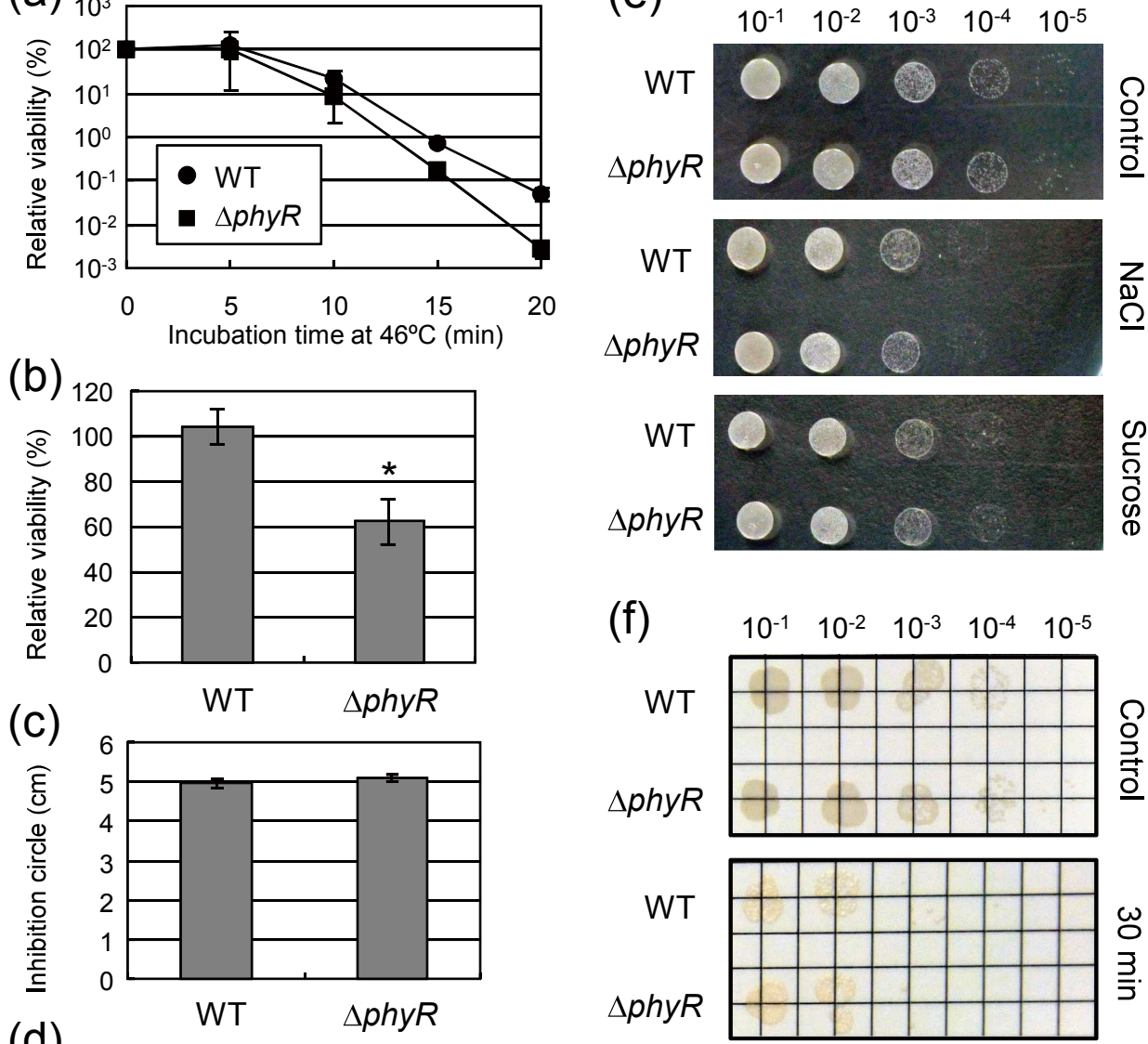

(f)
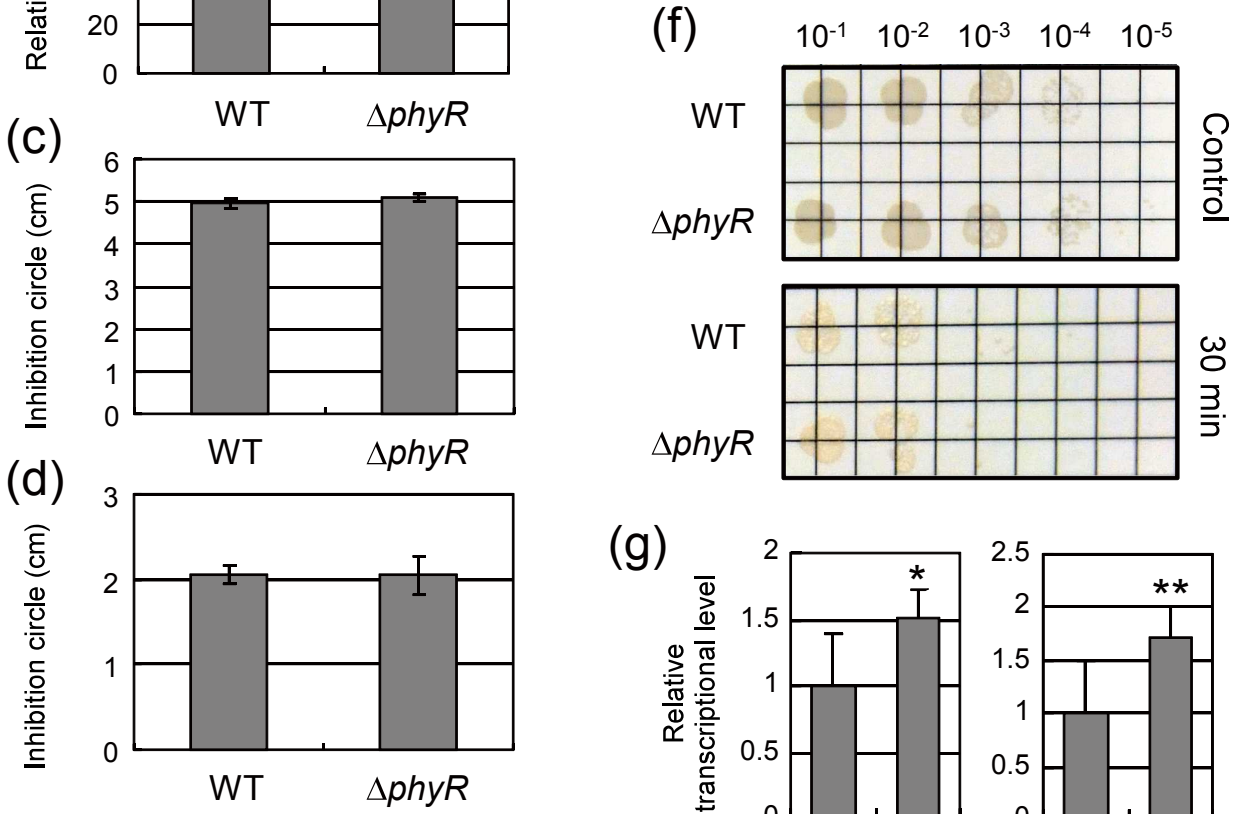

(g)

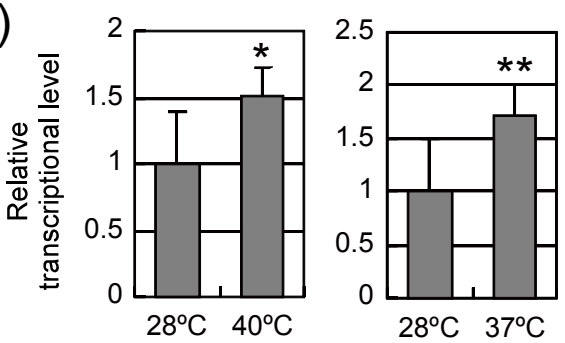

Figure 3 


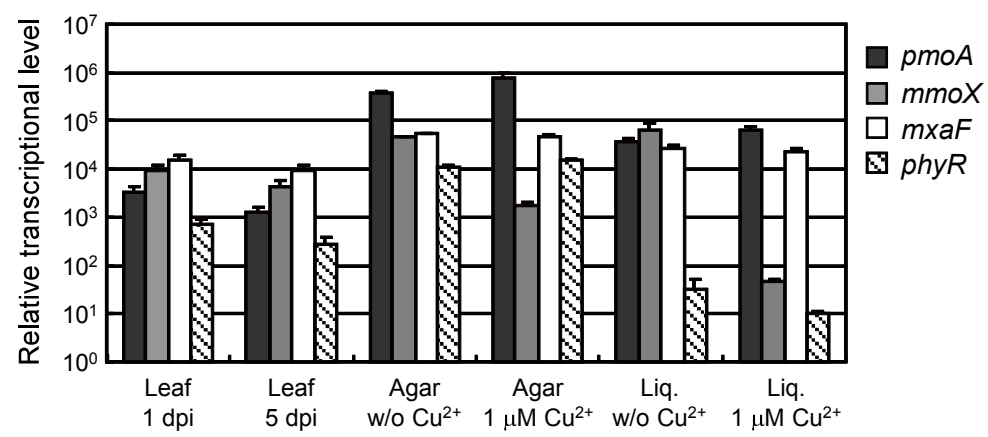

Figure 4 


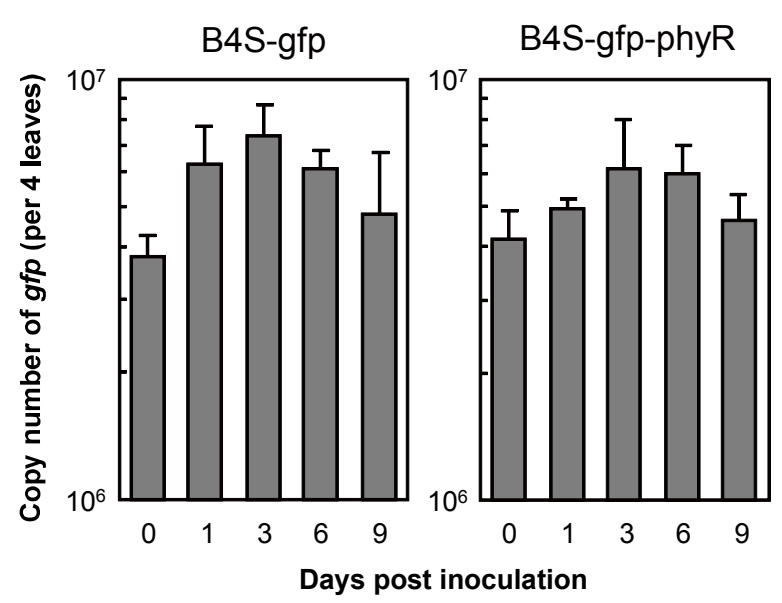

Figure 5 
Table S1 Primers used in this study.

\begin{tabular}{|c|c|c|}
\hline Use & Primer & Oligonucleotide sequence \\
\hline Cloning of phyR gene & $\begin{array}{l}\text { phyR424-Fw } \\
\text { phyR668-Re } \\
\text { phyR-INVu1 } \\
\text { phyR-INVu2 } \\
\text { phyR-INVd1 }\end{array}$ & $\begin{array}{l}\text { ATCATCGAGGACGAG } \\
\text { CGCTCCGGRTAGGCNGTGATGAA } \\
\text { CAGATCGAGCGCGATCAACG } \\
\text { TCTATGGCCGAGCTCCTCGA } \\
\text { GCGGTCGAGGCCATATCCAA }\end{array}$ \\
\hline phyR gene disruption & $\begin{array}{l}\text { phyR381-Fw } \\
\text { phyR1590-Re } \\
\text { phyR2001-Fw } \\
\text { phyR2770-Re }\end{array}$ & $\begin{array}{l}\text { CGGGATCCCCTATGGGGCATTTCGGCCC } \\
\text { GGGGTACCGAGCGTCGCCAGCACATAGG } \\
\text { GGGGTACCAACCCATAGGGAGGCGGTCG } \\
\text { GGAATTCGCATGCACGTCAGCCGGCCGCGATAC }\end{array}$ \\
\hline $\begin{array}{l}\text { Construction of } \\
\text { pK18mob-bla }\end{array}$ & $\begin{array}{l}\text { bla-Fw } \\
\text { bla-Re }\end{array}$ & $\begin{array}{l}\text { CATGCCATGGGAAAGGGCCTCGTGATACGC } \\
\text { GAAGATCTTTGGTCTGACAGTTACCAAT }\end{array}$ \\
\hline $\begin{array}{l}\text { Cloning of mxaF gene } \\
\text { promoter }\end{array}$ & $\begin{array}{l}\text { mxaF1023-INV } \\
\text { mxaF1541-INV } \\
\text { PmxaF-Fw } \\
\text { PmxaF-Re }\end{array}$ & $\begin{array}{l}\text { TCGTGCCCGGATCATAAGCAT } \\
\text { GAACCACATCTGCATGGATT } \\
\text { GCGGCCGCCGACTGCGGCGTGAGCAGGA } \\
\text { ATCCGACGAGTCCTCCTGCAACA }\end{array}$ \\
\hline Cloning of $g f p$ gene & $\begin{array}{l}\text { gfp-Fw } \\
\text { gfp-Re }\end{array}$ & $\begin{array}{l}\text { ATGAGTAAAGGAGAAGAACT } \\
\text { GCGGCCGCTTATTTGTAGAGCTCATCCA }\end{array}$ \\
\hline qPCR of $16 \mathrm{~S}$ rRNA gene & $\begin{array}{l}\text { Ma464 } \\
\text { Msins-647 }\end{array}$ & $\begin{array}{l}\text { TAATGACGGTACCTGGATAA } \\
\text { TCTCCCGGACTCTAGACC }\end{array}$ \\
\hline qPCR of $p m o A$ gene & $\begin{array}{l}\text { pmoA-qPCR-Fw } \\
\text { pmoA-qPCR-Re }\end{array}$ & $\begin{array}{l}\text { GCGAGTGGATCAATCGCTAC } \\
\text { GGCCGTGATCACATAGGAGC }\end{array}$ \\
\hline qPCR of $m m o X$ gene & $\begin{array}{l}\text { mmoX-qPCR-Fw } \\
\text { mmoX-qPCR-Re }\end{array}$ & $\begin{array}{l}\text { ATCAGTGCGCATTCATCAAC } \\
\text { СTTCATGCCСТTCCACАACG }\end{array}$ \\
\hline qPCR of $m x a F$ gene & $\begin{array}{l}\text { mxaF-qPCR-Fw } \\
\text { mxaF-qPCR-Re }\end{array}$ & $\begin{array}{l}\text { CGTGAACTTCATGCTGCTCA } \\
\text { TTATCGGCGGAGATCAGATC }\end{array}$ \\
\hline qPCR of $p h y R$ gene & $\begin{array}{l}\text { phyR-qPCR-Fw } \\
\text { phyR-qPCR-Re }\end{array}$ & $\begin{array}{l}\text { TGGCGACCGATGTGCTCATC } \\
\text { GCGACGACTCTATGGCCGAG }\end{array}$ \\
\hline qPCR of $g f p$ gene & $\begin{array}{l}\text { gfp-qPCR-Fw } \\
\text { gfp-qPCR-Re }\end{array}$ & $\begin{array}{l}\text { CACTGGAGTTGTCCCAATTC } \\
\text { AGGTAGTTTTCCAGTAGTGC }\end{array}$ \\
\hline
\end{tabular}

Underlined sequences are the incorporated restriction enzyme sites.

a, b the primers are referenced from FEMS Microbiol. Lett. (2001) 198:91-97 and FEMS Microbiol. Ecol. (2003) 43:299-308, respectively. 


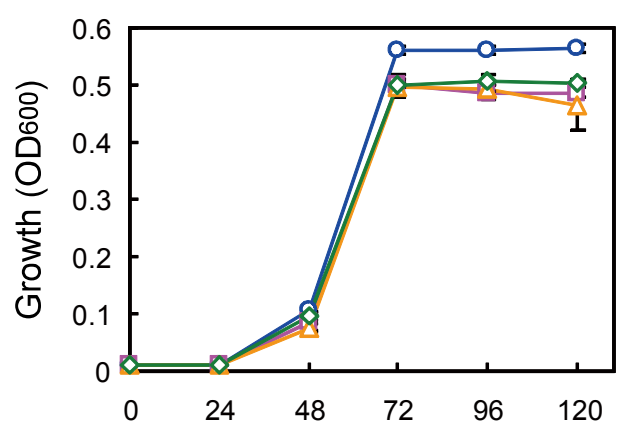

- - B4S (WT)

$\triangle$ B4S-gfp

$-\square$ B4S-phyR

$\prec$ B4S-gfp-phyR

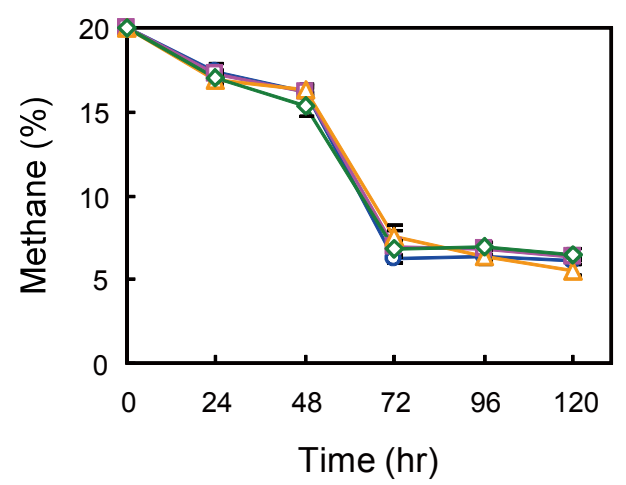

Figure S1 
Methylobacterium Bradyrhizobium Methylocella Sinorhizobium

Methylobacterium Bradyrhizobium Methylocella Sinorhizobium

Methylobacterium Bradyrhizobium Methylocella Sinorhizobium

Methylobacterium Bradyrhizobium Methylocella Sinorhizobium

Methylobacterium Bradyrhizobium Methylocella Sinorhizobium

Methylobacterium Bradyrhizobium Methylocella Sinorhizobium

Methylobacterium Bradyrhizobium Methylocella Sinorhizobium

Methylobacterium Bradyrhizobium Methylocella Sinorhizobium

Methylobacterium Bradyrhizobium Methylocella Sinorhizobium

Methylobacterium Bradyrhizobium Methylocella Sinorhizobium

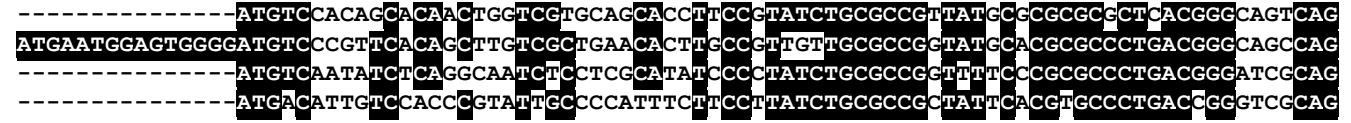

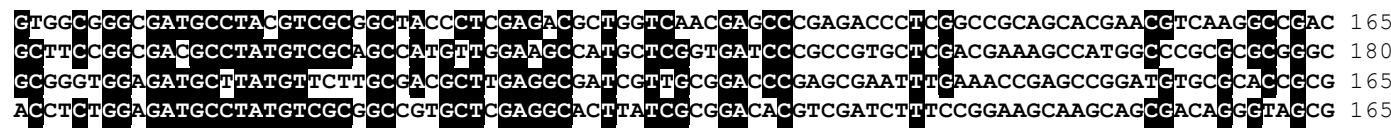

CTCTTCCGCGTCTTCACGCGGATCTGGAATTCGCTTTCCGTGAACGGCCACAGCGATCAGGTGCAGCACGATT-TGCCG--------GCC 246 CTGTTCCGGCTGTTCACCCAGATCTGGAATTCCGTCTCCGTCAACGACGACTCCGAGGTGAC-CACCCTGCCGATGCCG---1 CTCTACCGGCTTTTTCTCAAGGTTTGGAGCTCGGTCTCGGTCAATGATCACGTCGACGAAGTCGGATTTTCCGGCGACGAGATCGGCGCT 255
TTGTTCCGTCTCTTCACATCCATGTTCGGCTCGTCTTCCGTCCTCGTGC---CGGAGCCGGTATCGCCCTTTGCCTGGGACAGCGCGCA 252

GAAGTTCGGCTCGGCCAGATCACGCCGCTTCCCCGGCAGGCTTCCTGCTCTCGTGCCTCGAAGGCTTTTCGGAGGAGGATGCGGGCGTG 336
GAGCGGCGGTGTCGAACATCACGCCGTGCCGCGCAGGCCTTCCTGCTGCTTTCGCTCGAGGGATTTCGGAGAGGAGTCGCCTTC 351 GAGCGGCGGCTGTCGAACATCACGCCGCTGCCGCGGCAGGCCTTCCTGCTGCTTTCGCTCGAGGGATTTTCGGAAGAGGAGGTCGCCTTC 351 TCCGTCAACCTCGCGGCGGTCTCGCCGCTCGCACGCCAGGCGTTCCTGCTCGTATCGGTCGAAGCGTTCACGCCACAGGAAGCCGCCGAA 342

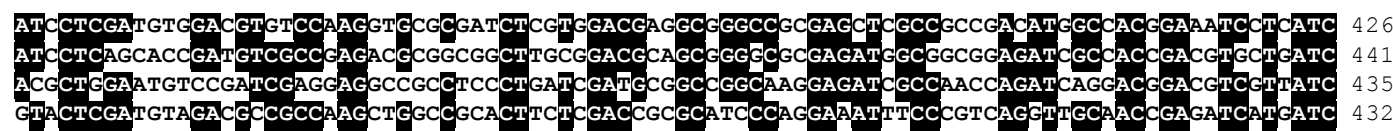

ATCGAGGACGACCGCTGATCGCCATGGATCTGGAAGCCCTGGTCGAAGGCCTCGGCCACAACGTCATCGGCGTGGCCCGCACCCGCACC 516 ATCGAGGACGAGACCTTCATCGCDATGGACCTCGAGAGCTGGTGAAGAATCTCGGCCACAACGTCGTCGGCGTCGCGCGCACGCATGCC 531 ATCGAGGACGAGCCCTTTATCGCGCTGGATCTGCAGACGCTGGTGGAGGAGCAGGGACACCGCGTCATCGCCGTCGCGCGCACGCACCGC 525 ATCGAGGACGAGCCGCTGATCGCGATCGACATCGAGCAAATGGTCGAAAGCCTCGGCCACAGCGTGACCGGGATCGCACGCACCAAGGAC 522

GAAGCGGTCAAGATCGCCTCCGAGAGCAAGCGCCCCGGCTTATCCTCGCCGACATTCAGCTCGCCGATGGCTCGTCGGGCCTGGATGCG 606 GATGCCGTGGCGCTGGC---CAAGAACAGGCGGCCCGCCTGATCCTCGCCGACATCCAGCTCGCTGACGGCTCGTCGGGGCTCGACGCG 618 GAAGCGATCGCCCTCTA---CGAGACGACGAAGCCGAACATGGTGCTCGCAGACATTCAGCTCGCGACGGCAGCTCGGGATCGATGCC 609

GTCAATGACCTGCTGAAGACCTTCGAGGTGCCGGTGATCTTCATCACGGCCTATCCCGAGCGCTTCCTCACGGGCGAGCGCCCCGAGCCG 696 GTCAACGAATTGCTGCGCACCTTCGAGGTGCCGGTGGTGTTCATCACCGCCTACCCGGAGCGCTTCCTCACCGGCGAGCGCCCGGAGCCC 708 GTCAACGAAATTCTTGAGTCGTTCTCCGTTCCCGTCATCTTCATCACAGCCTATCCGGAACGCTTCCTGACAGGAGCGCCGCCGGAGCCC 702 GTCAACGAAATCCTGAAGACGGCCGCCGTTCCGGTGATTTTCATCACCGCCTTCCCGGAGCGTCTCCTGACAGGTGAACGTCCCGAGCCC 699

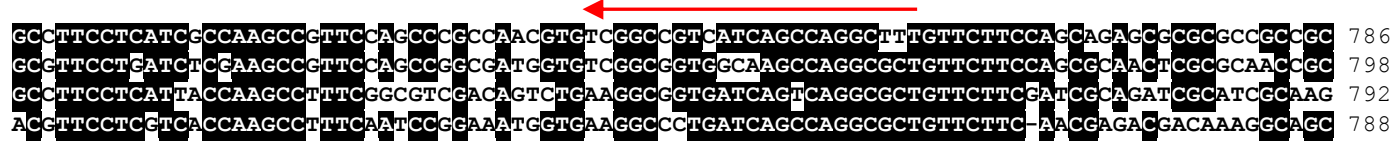
GAGGCGCACAACGCCTGA---:------- 804
-ACGCCCAAGGCGCCCGCGGCGTAA------ 822
GAAGAACAGGCTTCGAAGGGCGCGCTGGTCTGA 825
-- CGCCTGA--- 